\title{
Arthropods of Canadian grasslands: a retrospective of a 40-year project of the Biological Survey of Canada
}

\author{
K.D. Floate, ${ }^{1}$ J.D. Shorthouse, D.J. Giberson, H.A. Cárcamo
}

\begin{abstract}
The Biological Survey of Canada initiated a project in 1979 to collect and synthesise information on the native arthropod fauna of the vanishing grassland habitats of Canada. At that time, it was thought that the Canadian arthropod fauna might comprise about 66000 species. Recent studies suggest that the fauna may exceed 100000 species, of which $>25 \%$ may occur in the Prairies Ecozone. Results of this near 40-year project have been published in four volumes of the Arthropods of Canadian Grasslands monograph series of the Biological Survey of Canada. Here, the editors of this series review the grasslands project of the Biological Survey of Canada, summarise the contents of the volumes, and discuss current knowledge on the diversity of the grasslands arthropods of Canada. Whereas information on the species richness of some groups in the Prairies Ecozone is largely complete, information on the diversity of many other groups remains sparse. Reviewing the steps between initiation and publication of the Arthropods of Canadian Grasslands series may aid development of similar projects elsewhere. Identifying knowledge gaps will direct future research efforts. Identifying the diversity of grassland arthropods, their distribution and abundance, and the ecosystem services that they provide will facilitate efforts to conserve the remaining grassland habitats in Canada.
\end{abstract}

\section{Introduction}

The grassland habitats of Canada and their associated arthropod faunas have been dramatically altered since European settlement in the late 1800s. With < 1000 non-indigenous people before 1870, estimated numbers on the Prairies Ecozone increased to 57000 by 1881 and 99000 by 1891 (Willms et al. 2011). The population reached 3.5 million by 1981 and surpassed 4.5 million by 2006 (Statistics Canada 2006). With the increase in population, there has been a concurrent decrease in native habitats with at least $87 \%$ of the $443000 \mathrm{~km}^{2}$ of the region now converted to farmland (Coristine and Kerr 2011). Additional sources of disturbance include urban sprawl, water impoundments, drainage of natural wetlands, plus resource extraction, and its supporting infrastructure. Lands used to graze cattle have been fragmented by pipelines, railways, and roads, which has increased the invasion of native plant communities by exotic species (Vujnovic et al. 2002; Desserud et al. 2010) and has altered animal communities. About half of Canadian farms (and 80\% of the farmland) occur in the prairies (Sauchyn and Kulshreshtha 2008). Given this concentrated activity in a region that represents only $5 \%$ of the land base of Canada, it is not surprising that many of the native plant and animal species associated with the once vast prairies of Canada are now threatened and endangered (Coristine and Kerr 2011; Hall et al. 2011).

In 1979, the Biological Survey of Canada (BSC) initiated a project to collect and synthesise information on the native arthropod fauna of undisturbed grassland habitats before these habitats were forever lost (Danks 2016, 2017). Over nearly 40 years, the BSC has promoted research on grassland habitats through newsletters, special symposia, and BioBlitzes (field collecting trips

Received 19 May 2017. Accepted 30 July 2017. First published online 27 September 2017.

K.D. Floate, ${ }^{1}$ H.A. Cárcamo, Lethbridge Research and Development Centre, Agriculture and Agri-Food Canada, Lethbridge, Alberta, T1J 4B1, Canada

J.D. Shorthouse, Department of Biology, Laurentian University, Sudbury, Ontario, P3E 2C6, Canada

D.J. Giberson, Department of Biology, University of Prince Edward Island, 550 University Avenue, Charlottetown, Prince Edward Island, C1A 4P3, Canada

${ }^{1}$ Corresponding author (e-mail: Kevin.Floate@agr.gc.ca).

Subject editor: Andrew Smith

doi:10.4039/tce.2017.46 
to document regional faunas). These activities culminated in the publication of four volumes of the BSC's Arthropods of Canadian Grasslands series (Shorthouse and Floate 2010; Floate 2011b; Cárcamo and Giberson 2014; Giberson and Cárcamo 2014). This retrospective is provided to increase awareness of the grasslands project, record some of the "lessons learned", identify knowledge gaps, and facilitate future progress on this initiative.

\section{The Prairies Ecozone and its constituent ecoregions}

Grasslands are open expanses dominated by graminoids and forbs, where trees or shrubs comprise $<10 \%$ of the ground cover (White 1983). The grasslands of Canada occur mainly in the Prairies Ecozone, which encompasses the south-central portions of Alberta, Saskatchewan, and Manitoba, Canada; i.e., the Prairie Provinces (Fig. 1) (Shorthouse 2010b). This ecozone is the northernmost extension of the Great Plains of North America, which extends from the Rocky Mountains east to the Mississippi River in the United States of America and south into northern Mexico (Pieper 2005). Lesser and scattered expanses of Canadian grasslands occur in interior valleys of British Columbia and the Yukon, and in southern Ontario (Shorthouse 2010c).

The Canadian Prairies Ecozone has a generally flat topography with a continental climate; i.e., long and cold winters with hot and short summers (Ecological Stratification Working Group 1995). The Rocky Mountains to the west deplete moisture-bearing air-masses from the Pacific Ocean resulting in a subhumid to semiarid

Fig. 1. Map of Canada showing the location of ecoregions within the Prairies Ecozone. Reprinted with permission from Shorthouse (2010b).

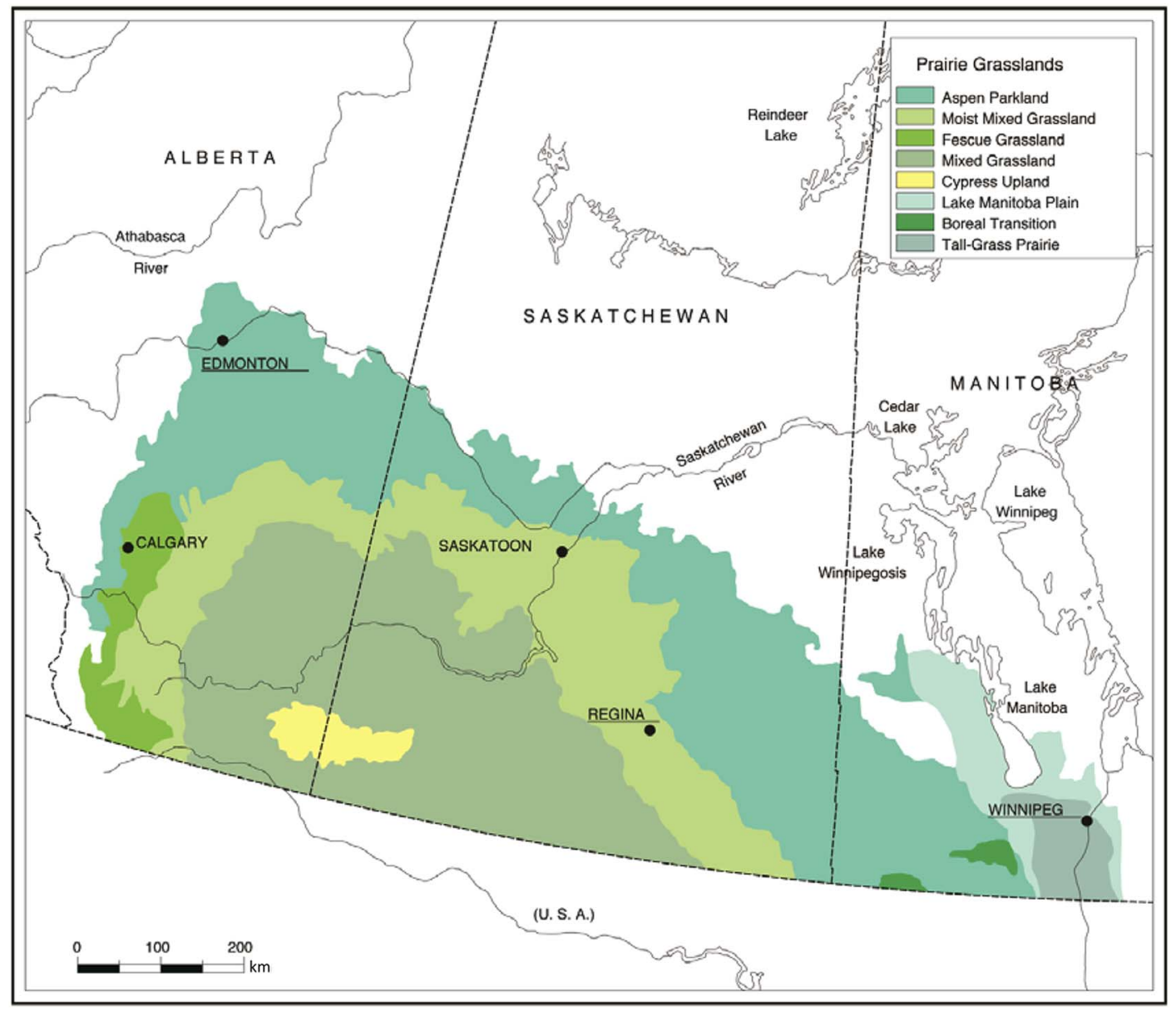


climate. Climate change predictions are for increased aridity following greater numbers of dry years (Sauchyn and Kulshreshtha 2008). An overview of the climate of the ecozone and climate change is provided by McGinn (2010). A more recent summary of climate change for Canada is provided by Bush et al. (2014). They report that average annual surface air temperature has increased by $1.5^{\circ} \mathrm{C}$ from 1950 to 2010 , with particularly strong trends during winter and spring seasons in the western part of the country. For example, mean maximum and mean minimum temperatures during spring on the prairies from 1950 to 1989 have increased by $3.8^{\circ} \mathrm{C}$ and $2.8^{\circ} \mathrm{C}$, respectively (Skinner and Gullett 1993). In combination with killing frosts occurring later in the fall, this has resulted in a general trend towards a longer growing season (Qian et al. 2010) with endemic species experiencing milder winters.

Climate change directly and indirectly affects arthropod populations, but studies of direct effects in the Canadian Prairies Ecozone have been largely limited to exotic species that are pests of crops (Olfert and Weiss 2006; Olfert et al. 2011, 2016). One probable impact is changes in the ranges of grassland species (Scudder 2010a), though these changes are not straightforward, since species of arthropod in Canadian grasslands are adapted to cold and dry winters, and are not just extensions of the fauna from grasslands further south (Scudder 2014b). Further, changes in the phenology of flowering plants may disrupt plant-pollinator interactions to the detriment of some species (Memmott et al. 2007). An overview of climate change and its effects on biodiversity in Canada is provided by Coristine and Kerr (2011) and Nantel et al. (2014).

The Prairies Ecozone extends over a wide geographical area and shows considerable variation in major landforms, climate, soils, precipitation, vegetation, and human activity patterns/ uses. This variation is captured by the separation of the ecozone into eight ecoregions: Aspen Parkland, Moist Mixed Grassland, Fescue Grassland, Mixed Grassland, Cypress Upland, Lake Manitoba Plain, Tall-Grass Prairie, and Boreal Transition (Fig. 1) (Ecological Stratification Working Group 1995).

Variation in annual precipitation in the Prairies Ecozone (which increases from west to east) also results in three types of prairie grassland, distinguished by the height of the dominant grass species: western shortgrass prairie $(0.3-0.5 \mathrm{~m}$ height, $260-375 \mathrm{~mm}$ average annual precipitation), a central midgrass or mixedgrass prairie (0.8-1.2 m height, 375-625 mm), and an eastern tallgrass prairie (1.8-2.4 m height, 625-1200 mm) (Anderson 2006). Tall-grass prairie is the least protected type of grassland habitat with $<1 \%$ remaining in an undisturbed state (Pearn and Hamel 2014). More detailed synopses on features of the Prairies Ecozone and its ecoregions are provided in Shorthouse (2010a, 2010b).

\section{Arthropod diversity on the Canadian prairies}

Danks (1979, 1988) reported 34000 known species of terrestrial arthropods in Canada, but estimated that $\sim 66000$ species occur in the country, including $~ 54000$ insect species ( 30000 currently known), 11000 species of arachnid (3000 known) and $\sim 900$ species of other terrestrial arthropods. Diverse groups thought to contain many undescribed or unrecorded species included Acari, Hemiptera, Coleoptera (especially Staphylinidae), Lepidoptera (especially Tineoidea), and particularly Diptera and Hymenoptera. The question of arthropod diversity in Canada was revisited by Hebert et al. (2016), who used results of DNA barcoding to reassess these earlier estimates. They concluded that there may be more than 100000 species of insects in Canada, including as many as 50000 species of Diptera and 30000 species of Hymenoptera. Similarly, Blagoev et al. (2016) used DNA barcoding to conclude that the number of species of spiders in Canada $(\sim 1460)$ may be underestimated by $30-50 \%$.

For the Canadian Prairies, early knowledge of arthropod diversity was spurred by the efforts of Edgar Strickland (1889-1962) (Hocking 1963; Byers and Cárcamo 2013) and Norman Criddle (1875-1933) (Holliday 2006). These two English immigrants are pioneers of entomology in Alberta and Manitoba, respectively. In 1913, Strickland founded the Dominion Entomological Laboratory in Lethbridge, Alberta, and Norman Criddle was appointed Entomological Field Officer in Manitoba. Their main activities focussed on finding ways to help farmers deal with serious pest outbreaks, including grasshoppers (Orthoptera: Acrididae), click beetles/wireworms (Coleoptera: Elateridae), and cutworms (Lepidoptera: Noctuidae). However, they were both avid collectors and contributed significant knowledge on a wide array of arthropods 
that provided baseline data for future studies. Strickland produced checklists for click beetles, biting flies, parasitic wasps, Hemiptera, and leafhoppers (Hemiptera: Cicadellidae) and many other publications (Hocking 1963). Criddle published at least 65 articles with entomological content, with particular focus on the presence, ecology, and control of grasshoppers (Gibson and Crawford 1933). He also contributed countless first records for the prairies. His systematic and thorough collecting near his home at Aweme in southwestern Manitoba has allowed for valuable historical analyses for selected taxa; e.g., Coleoptera: Carabidae (Holliday et al. 2014).

\section{The Arthropods of Canadian grasslands initiative}

The BSC was initiated in 1977 to "establish the basic inventory and natural history of the Canadian insect fauna, through collection and research on a comprehensive geographical scale and a publication programme for a series of identification and reference volumes" (Danks 2016). The Arthropods of Canadian Grasslands was one of several BSC projects, each targeting a different region or habitat of the country. The Arthropods of Canadian Grasslands project officially started in 1979 with a focus on the faunas of undisturbed grasslands (this was later expanded to include disturbed areas as well) and the development of a network of arthropod workers interested in grassland habitats. A Grasslands Arthropods Newsletter was established to facilitate communication among researchers with 11 issues published; i.e., 1983-1990, 2000-2005 (http://biologicalsurvey.ca/pages/read/arthropodsof-canadian-grasslands-index). The publication gap between 1990 and 2000 was a period of lower interest in the project, which triggered a concerted effort to rejuvenate the project in 1999. The BSC organised a series of intensive collecting events (BioBlitzes) to various grassland sites; e.g., Onefour, Alberta, 2001; Dunvegan, Alberta, 2003, Aweme, Manitoba, 2004; Waterton Lakes National Park, Alberta, 2005; Riding Mountain National Park, Manitoba, 2007; Peace River Valley, British Columbia, 2015; and Carmacks, Yukon, 2016 (Danks 2016). The objectives of the project were formalised in a grasslands "prospectus" in 2002, and formal symposia were held at national meetings of the Entomological
Society of Canada (2002, 2010). Results of this activity have been published by the BSC in a monograph series titled Arthropods of Canadian Grasslands. Four volumes (totalling 1621 pages) have been published thus far (Shorthouse and Floate 2010; Floate 2011b; Cárcamo and Giberson 2014; Giberson and Cárcamo 2014).

Several challenges were overcome to produce the monograph series. Potential contributors voiced different concerns regarding the scope and content of submissions. Some taxonomists felt the need for more study before undertaking a grasslands review, ecologists felt excluded from what they perceived to be primarily a taxonomic project, and applied entomologists felt a focus on undisturbed grasslands was too narrow. Thus, the objectives of the Arthropods of Canadian Grasslands project were expanded while maintaining its underlying objectives; i.e., to increase awareness of the vanishing grasslands in Canada and their associated arthropods, and to provide baseline references for future studies of arthropods in these habitats. As a result, submissions highlighting arthropod ecology, different habitats (including agroecosystems), specific grassland sites, species summaries and species checklists were all encouraged. Contributors also were encouraged to target a broad audience, including teachers, farmers, ranchers, naturalists, and researchers interested in the Prairies Ecozone. To make the products more attractive to this audience, contributors were encouraged to make liberal use of colour photographs, maps, images, and easily understood summary tables. The use of colour images was made practical by advances in print technology over the period that the BSC has been operating, which dramatically reduced the cost of colour plates.

The format in which the books were published was affected by recent advances in publishing, since the books could be produced (including professional copy-editing and page layout) as highquality PDF files made available on the BSC website for free download (http://biologicalsurvey. $\mathrm{ca} /$ monographs/read/17). This reduced costs by eliminating the need to print and store quantities of books. Authors and other grassland workers pushed strongly for availability of hard-copy books, leading to the decision by the not-for-profit BSC to provide the option of hard-copy publication through a "print-on-demand" service. To reduce costs for 
the authors, page charges were at least partially subsidised by the BSC's publishing arm for authors with limited funds. This hybrid model of free PDFs with the option to purchase print copies has since been adopted for other BSC monographs (e.g., Lindquist et al. 2016).

The books cover an extensive array of topics relating to grassland arthropods. The first volume provides a general description of the biological and climatic aspects of the Prairies Ecozone and broad ecological factors that influence diversity of arthropods and their life histories (Shorthouse and Floate 2010). Topics in specific chapters range from summaries of arthropods from specific habitat types (e.g., soils, rose or cottonwood galls, tallgrass prairie) or taxonomic groups. The second volume is an examination of the arthropod fauna in modified habitats of the Prairies Ecozone, almost all of which has been converted into agroecosystems (Floate 2011b). Topics begin with a review of the effects of European settlement on the habitat, then cover arthropod relationships (species patterns, species at risk, control strategies, and habitats such as ponds and streams, crops, livestock systems, and stored grains). The most recent two volumes (Cárcamo and Giberson 2014; Giberson and Cárcamo 2014) provide checklists and ecological, distributional/ biogeographical, and/or habitat information for 24 higher level taxa (from family to class) represented in the Prairies Ecozone. These are in addition to the five species lists or summaries published in volumes 1 and 2 (see Table 1 for a summary of species diversity information from these books).

The success of the Arthropods of Canadian Grasslands initiative can be partially assessed by awareness of the grassland publications among the target audience; i.e., students, researchers, and the general public. Awareness was initially examined using Google with individual searches performed by chapter title on 26-28 March 2017. A total of 602 results were identified, spanning a wide range of sources; e.g., personal webpages, online industry magazines, online identification guides, and sources more specifically academic in nature.

To assess more precisely the uptake of these chapters by the academic community, we then repeated these searches in Google Scholar during this same time frame and classified results by source; i.e., scientific journals, graduate student theses, Arthropods of Canadian Grasslands chapters, books (and book chapters), and "other" (Fig. 2). Citations from other Arthropods of Canadian Grasslands chapters were excluded from the "book" category to avoid overestimating awareness of the Arthropods of Canadian Grasslands series. The "other" category included government reports, reference guides, or sources that did not clearly fall into the remaining categories. A total of 268 citations to the 53 chapters in the Arthropods of Canadian Grasslands series were identified, of which 19 were self-citations. Excluding selfcitations and citations in Arthropods of Canadian Grasslands chapters, the most cited chapters were reviews of taxonomic groups that included key pest species (Hamilton and Whitcomb 2010; van Herk and Vernon 2014) or topics of broader interest; e.g., weather (McGinn 2010), arthropods of cattle dung (Floate 2011a), and arthropods introduced as biocontrol agents (De Clerck-Floate and Cárcamo 2011). Examination of journal titles and the thesis granting universities identified many located outside of North America.

As of 31 March 2017, only about 17 hard copies have been sold for each volume of the Arthropods of Canadian Grasslands series via the print-on-demand option. Thus, providing this option appears to have provided little tangible benefit for dissemination of the series. Uptake of the print-on-demand option has been greater for other BSC monographs; e.g., 70 copies of A Handbook to the Ticks of Canada (Ixodida: Ixodidae, Argasidae) (Lindquist et al. 2016) have been sold in the first four months since its release (D. Langor, personal communication). However, linking to the chapters through online sites shows that chapters are being downloaded and viewed. A paper on stoneflies (Plecoptera) of the Prairie Provinces in volume 3 (Dosdall and Giberson 2014) was downloaded through ResearchGate (www.researchgate.net) more than 100 times between 5 January 2016 and 20 April 2017. Since 1 January 2017, the Arthropods of Canadian Grasslands webpage (http://biologicalsurvey.ca/ monographs/read/17) has been accessed 383 times (J. Elofson, personal communication).

\section{What have we learned from the grassland arthropods initiative?}

The BSC has been well positioned to lead an initiative assessing arthropod diversity in the 
Table 1. Arthropod diversity recorded for the Prairies Ecozone of Canada (or for the Prairie Provinces - bold font).

\begin{tabular}{|c|c|c|c|c|c|}
\hline Class & Order and suborder & Family & $\begin{array}{l}\text { Number of } \\
\text { genera }\end{array}$ & $\begin{array}{l}\text { Number of } \\
\text { species }\end{array}$ & Reference \\
\hline \multirow[t]{3}{*}{ Diplopoda } & Julida & 4 & 6 & 6 & Snyder (2014) \\
\hline & Chordeumatida & 2 & 2 & 3 & Snyder (2014) \\
\hline & Polydesmida & 1 & 1 & 1 & Snyder (2014) \\
\hline \multirow[t]{3}{*}{ Chilopoda } & Geophilomorpha & 2 & 2 & 2 & Snyder (2014) \\
\hline & Lithobiomorpha & 2 & 3 & 3 & Snyder (2014) \\
\hline & Scutigeromorpha & 1 & 1 & 1 & Snyder (2014) \\
\hline Pauropoda & - & - & - & - & Snyder (2014) \\
\hline Symphyla & - & - & - & - & Snyder (2014) \\
\hline \multirow[t]{2}{*}{ Crustacea } & Amphipoda & 18 & - & 44 & Snyder (2014) \\
\hline & Isopoda & - & - & - & Snyder (2014) \\
\hline \multirow[t]{7}{*}{ Arachnida } & Mesostigmata (plant mites) & 6 & 6 & 16 & Beaulieu and Knee (2014) \\
\hline & Trombidiformes (plant mites) & 13 & 45 & 118 & Beaulieu and Knee (2014) \\
\hline & Prostigmata (soil mites) & 21 & 16 & 18 & Behan-Pelletier and Kanashiro (2010) \\
\hline & Sarcoptiformes (plant mites) & 9 & 22 & 30 & Beaulieu and Knee (2014) \\
\hline & Oribatida (soil mites) & 34 & 52 & 74 & Behan-Pelletier and Kanashiro (2010) \\
\hline & Endeostigmata (soil mites) & 5 & 2 & 2 & Behan-Pelletier and Kanashiro (2010) \\
\hline & Astigmatina (feather mites) & 20 & 73 & 174 & Galloway et al. (2014) \\
\hline Arachnida & Araneae & 26 & 250 & 767 & Cárcamo et al. (2014) \\
\hline Entognatha & Collembola & 9 & 23 & 69 & Lindo (2014) \\
\hline \multirow[t]{29}{*}{ Insecta } & Phthiraptera & 4 & 54 & 183 & Galloway et al. (2014) \\
\hline & Plecoptera & 3 & 59 & 131 & Dosdall and Giberson (2014) \\
\hline & Odonata & 9 & 38 & 124 & Cannings (2014a) \\
\hline & $\begin{array}{l}\text { Orthoptera (British } \\
\text { Columbia and Yukon) }\end{array}$ & 10 & 31 & 48 & Miskelly (2014) \\
\hline & Hemiptera (Heteroptera) & 39 & 229 & 582 & Scudder (2014a) \\
\hline & $\begin{array}{l}\text { Hemiptera } \\
\text { (Auchenorrhyncha) }\end{array}$ & Cicadellidae & 16 & 174 & Hamilton (2014) \\
\hline & Hemiptera (Aphidoidea) & 3 & 110 & 357 & Foottit and Maw (2014) \\
\hline & Diptera & Simuliidae & 3 & 18 & Currie (2014) \\
\hline & & Culicidae & 7 & 25 & Lysyk and Galloway (2014) \\
\hline & & Ceratopogonidae & 1 & 26 & Lysyk and Galloway (2014) \\
\hline & & Tabanidae & 5 & 30 & Lysyk and Galloway (2014) \\
\hline & & Chironomidae & $50+$ & 136 & $\begin{array}{l}\text { (Mason 1983; Miyazaki and } \\
\text { Lehmkuhl 2011) }\end{array}$ \\
\hline & Diptera & Asilidae & 37 & 134 & Cannings (2014b) \\
\hline & Coleoptera & Carabidae & 72 & 398 & Holliday et al. (2014) \\
\hline & & Elateridae & 51 & 361 & van Herk and Vernon (2014) \\
\hline & & Tenebrionidae & 12 & 31 & Bouchard and Bousquet (2014) \\
\hline & & Dryophthoridae & 1 & 9 & Anderson et al. (2014) \\
\hline & & Brachyceridae & 6 & 13 & Anderson et al. (2014) \\
\hline & & Curculionidae & 109 & 273 & Anderson et al. (2014) \\
\hline & Lepidoptera & 61 & 758 & 2232 & Pohl et al. (2014) \\
\hline & Hymenoptera & Formicidae & 4 & 53 & Glasier and Acorn (2014) \\
\hline & & Ichneumonidae & 299 & 1160 & Schwarzfeld (2014) \\
\hline & & Braconidae & 78 & 251 & Sharanowski et al. (2014) \\
\hline & & Colletidae & 2 & 31 & Sheffield et al. (2014) \\
\hline & & Andrenidae & 5 & 92 & Sheffield et al. (2014) \\
\hline & & Halictidae & 7 & 90 & Sheffield et al. (2014) \\
\hline & & Melittidae & 1 & 1 & Sheffield et al. (2014) \\
\hline & & Megachilidae & 9 & 81 & Sheffield et al. (2014) \\
\hline & & Apidae & 17 & 92 & Sheffield et al. (2014) \\
\hline
\end{tabular}

Note: Unless otherwise stated, the information was taken from the publications of the Biological Survey of Canada as given in the reference column. 
Fig. 2. Sources identified using Google Scholar that cite chapters in the Arthropods of Canadian Grasslands monograph series. The Arthropods of Canadian Grasslands (ACG) category identifies selfcitations, i.e., citations to other chapters in the Arthropods of Canadian Grasslands monograph series. The "other" category includes government reports, reference guides, or sources that do not clearly fall into the remaining categories.

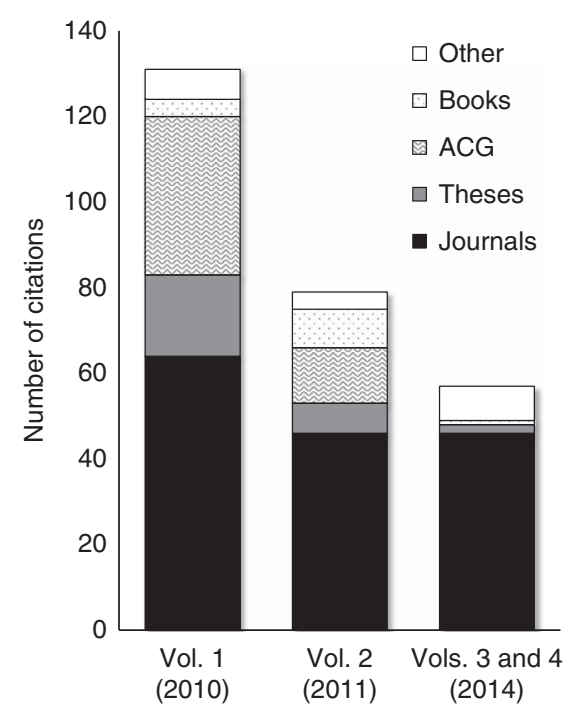

prairie grasslands, due to its collaborative approach in bringing together researchers to synthesise known information and generate new data (Danks 2016, 2017). Through meetings organised by the BSC, entomologists from across the country met in Ottawa, Ontario at least annually to discuss knowledge gaps and propose solutions to fill them. These meetings, coupled with symposia at annual entomology meetings and organised field trips (BioBlitzes) to different habitats, engaged a broad community of researchers who ultimately contributed to the projects and their outputs, including monographs and newsletters (Danks 2017). A broader understanding of the arthropod species composition of prairie grasslands has been achieved through the grasslands project, as well as information on the remaining gaps. In the sections below, we summarise some of the findings of the project and provide suggestions for future directions.

Diversity patterns. Summaries from the Arthropods of Canadian Grasslands monograph series (Shorthouse and Floate 2010; Floate 2011b; Cárcamo and Giberson 2014; Giberson and Cárcamo 2014) show that taxonomic knowledge for the Prairies Ecozone varies markedly among arthropod groups, but is generally more complete for insects than for non-insects (see also Table 1 for additional references). Species lists are generally complete for grasslands Lepidoptera (Pohl et al. 2014) and Orthoptera (Vickery and Kevan 1985), but non-lepidopteran orders may have both well known or sparsely studied families, or species lists that are defined by political jurisdiction rather than by ecozone; e.g., Coleoptera (Bousquet et al. 2013). This latter deficiency has been partially addressed with the publication of Prairies Ecozone checklists (along with habitat and ecological information in many cases) for several families of beetles in the Arthropods of Canadian Grasslands series or other recent monographs. These include the Carabidae (Holliday et al. 2014), Elateridae (van Herk and Vernon 2014), Tenebrionidae (Bouchard and Bousquet 2014), Dytiscidae (Larson et al. 2000), and families of the Curculionoidea (Anderson et al. 2014). Staphylinidae (rove beetles) have been largely overlooked at the ecozone level, even though it is the most speciose beetle family in Canada; i.e., 1652 recorded species and subspecies (Klimaszewski et al. 2015). Ecozone synopses for Chrysomelidae, Scarabaeidae, and other groups of beetles have not yet been done. For Hemiptera, synopses are now available for Heteroptera (Scudder 2014a), Aphidoidea (Foottit and Maw 2014), and Cicadellidae (Hamilton and Whitcomb 2010; Hamilton 2014). Within the Hymenoptera, there are extensive checklists for Apiformes (Sheffield et al. 2014), Braconidae (Sharanowski et al. 2014), Formicidae (Glasier and Acorn 2014), and Ichneumonidae (Schwarzfeld 2014). Among families of Diptera, there are recent synopses for Asilidae (Cannings 2014b), and the biting flies (Simulidae - Currie (2014) and Ceratopogonidae, Culicidae, and Tabanidae Lysyk and Galloway (2014)). However, only 369 species of flies were reported in the Arthropods of Canadian Grasslands series (combined across families).

The prairies also support many species of aquatic insects that inhabit natural wetlands, ponds, and rivers (Wrubleski and Ross 2011). 
These aquatic groups are generally poorly known, with the exception of the biting flies mentioned above, primarily because there are few taxonomic keys for immature stages in most groups. Immature stages (which live in water) are commonly collected in aquatic surveys, and identification is usually to "lowest practical taxon", which for most aquatic insect groups is to genus. The comprehensive Introduction to the aquatic insects of North America (Merritt et al. 2008) provides genus-level keys for most groups, and lists regional species keys where available, but few of these target regions in Canada, including the Prairies Ecozone. There are many lists of taxa associated with specific prairie streams or ponds (e.g., Cobb and Flannagan 1990; Miyazaki and Lehmkuhl 2011; Parker 2017), but only a few of these lists identify the majority of taxa to species; e.g., Cobb and Flannagan (1990). Therefore, there are few current synthetic treatments for aquatic insects of the Prairies Ecozone, though exceptions include the Odonata (Cannings 2014a), Plecoptera (Dosdall and Giberson 2014), and the Ephemeroptera in Saskatchewan (Webb 2002). For some aquatic insect groups, up-to-date checklists for broad regions or jurisdictions are available online, but these do not allow for analyses at the ecozone level; e.g., Ephemeroptera (Jacobus and McCafferty 2017), Plecoptera (DeWalt et al. 2017), and Trichoptera (Rasmussen and Morse 2016).

From existing checklists, we can conclude that the Prairies Ecozone supports at least $25 \%$ of the $\sim 34000$ species of arthropods so far recorded in Canada (Danks 1988). This estimate derives from a compilation of taxa reported from the Prairie Provinces, in most cases specific to the Prairies Ecozone (Table 1). These lists, taken from the Arthropods of Canadian Grassland series, identify about 8200 species, representing 2518 genera in 309 families, or 22 orders in nine classes. Extrapolating from the findings for well-studied groups, this percentage is expected to increase with further taxonomic studies. Among speciose insect orders, our taxonomic knowledge for the Prairies Ecozone is perhaps most complete for Lepidoptera (2232 species, representing $43 \%$ of the Canadian total - Pohl et al. 2014), Hemiptera (Heteroptera) (41\% of the known Canadian fauna - Scudder 2014a), and Odonata (59\% of the known Canadian fauna - Cannings 2014a).
For Coleoptera, Diptera, and Hymenoptera, knowledge of the fauna varies widely by family. Ground beetles (Coleoptera: Carabidae) have been extensively studied in Canada (Lindroth 1961-1969) so few additional species are expected, and 44\% (398 species) of the Canadian total occurs in the Prairies Ecozone (Holliday et al. 2014). This compares to only $22 \%$ and $34 \%$ (respectively) of the Canadian darkling beetles (Tenebrionidae - 31 species) and weevils (Dryophthoridae - nine species, Brachyceridae 13 species, Curculionidae - 273 species) found in the Prairies Ecozone (Anderson et al. 2014; Bouchard and Bousquet 2014). The reported 387 species of bees (Hymenoptera: Apoidea, Apiformes) in the Ecozone represents $48 \%$ of the Canadian fauna (Sheffield et al. 2014). Among the well-known biting Diptera, only $11 \%$ (18 species) of the Canadian total for Simuliidae (black flies) are considered Prairies Ecozone residents (Currie 2014), and 30\% (25 species) of Culicidae (mosquitoes) are found in the zone (Lysyk and Galloway 2014).

Groups dominated by grassland specialists predictably have a high proportion of their Canadian species resident in the Prairies Ecozone. Orthoptera (grasshoppers) have been well studied in Canada (Vickery and Kevan 1985). Grassland habitats in British Columbia and the Yukon support 87 species, representing $57 \%$ of the Canadian fauna (Miskelly 2014). The species richness of the Prairies Ecozone may represent $65 \%$ of the Canadian fauna (Miskelly 2014).

The taxonomy of non-insect terrestrial arthropods is generally unresolved (Table 1), leading to difficulties in predicting diversity patterns for these groups. For Acari, perhaps $70 \%$ or more of the estimated 10000-15000 species in Canada are undescribed (Lindquist et al. 1979; Lumley et al. 2013). A square metre of grassland soil may contain up to 250 species and 150000 mites (Behan-Pelletier 2003). In addition, studies of grassland soils have generally focussed on Oribatidae mites, even though Prostigmatidae mites may be numerically more dominant (Behan-Pelletier and Kanashiro 2010). About 200 species of mites that feed above-ground on plants (Beaulieu and Knee 2014) are expected in the Prairies Ecozone. Interestingly, there appears to be little faunistic overlap between aboveground plant mites and soil mites. The two groups 
share 14 families and seven genera, but only two species (Beaulieu and Knee 2014; Galloway et al. 2014). About 200 species of mites are parasites of birds of the Prairies Ecozone (Galloway et al. 2014). If these estimates of species richness are correct, then $50 \%$ of plant feeding and $80 \%$ of parasitic species are known. In contrast, our taxonomic knowledge of ticks (Acari: Ixodida) is essentially complete. A recent synthesis reviews each of the 40 species (10 genera) reported in Canada (Lindquist et al. 2016).

The taxonomy of Collembola (class Entognatha) is better known than that of mites, with a North American species key provided by Christiansen and Bellinger (1998). Skidmore (1995) provides a checklist for 412 species in Canada of an estimated total number of roughly 520 species expected (Danks 1988). We are aware of only three studies from the Prairie Provinces that report on the diversity of Collembola, and only two of these report on the Prairies Ecozone. Ten species were reported from seven sites in the Boreal Ecozone in northcentral Alberta (Berg and Pawluk 1984). A total of 12 species were reported from a site in southern Alberta (Scheffczyk et al. 2016). In all, 16 species were identified from tallgrass prairie, although species richness was likely underestimated due to methodology (Aitchison 1979). Using results of Skidmore (1995) and diversity studies for grasslands in the United States of America, Lindo (2014) provides a checklist of 69 species of Collembola known or likely to occur in the Prairies Ecozone.

Other non-insect arthropods and their relatives are even less known. There have been no studies in the Prairies Ecozone to assess species richness in Pauropoda (pauropods), Symphyla (garden centipedes), or terrestrial Crustacea (i.e., terrestrial Isopoda; wood lice, and pill bugs or sow bugs) (Snyder 2014). Only 10 species of Myriapoda (millipedes, centipedes) have been documented for the prairies (Snyder 2014), although 200 species were estimated to occur in Canada (Danks 1988). Given the generally dry climate of the Ecozone, the diversity of these groups is expected to be low. Tardigrades (water bears or moss piglets) were included as members of Arthropoda by Danks (1988) with an estimated Canadian total of 210 species. Tardigrades are no longer considered arthropods, although their phylogenetic relationships remain somewhat contentious (Giribet and Edgecombe 2012). They may have a rich diversity in the Prairies Ecozone given their remarkable ability to survive extreme temperatures and desiccation (Horikawa 2012). In a recent survey in three southern Alberta sites, an average of 20 tardigrades was collected per gram of moss, but these were not identified to species (Sorensen and Goater 2016). A total of 12 species or species groups of tardigrades were collected in an urban park in Calgary, Alberta, for which eight were first reports for the province and two were new records for Canada (Grothman 2011).

Our knowledge of speciose groups of noninsect arthropods is most complete for spiders, but knowledge gaps remain, and a grassland synthesis is still lacking. Danks (1988) and Bennett (1999), respectively, estimated a total of 1400 and 1500 described and undescribed species of spiders in Canada; Paquin et al. (2010) provide a species list of 1413 species for Canada and Alaska. Assuming a Canadian total of 1500 species, $94 \%$ of the spider species in Canada should have been described. However, recent results obtained with DNA barcoding indicate that the total number of species in Canada may range from 1900-2200, in which case 30-50\% remain undiscovered (Blagoev et al. 2016). A complete synthesis for spiders of the Prairies Ecozone is not available. However, 767 species were recorded from all Ecozones in the Canadian Prairie Provinces (Cárcamo et al. 2014), and 356 species are known from the grasslands and parkland areas of Alberta and Saskatchewan (Holmberg and Buckle 2002). Extrapolating from the insect taxa mentioned above, $40 \%$ or more of the national diversity for many groups occurs in the Prairies Ecozone. If there is a similar relationship for spiders, and assuming a total fauna of 1900-2200 species (Blagoev et al. 2016), then there are perhaps 760-880 species in the Prairies Ecozone.

The need for long-term and/or broad-scale studies. Comparison of the available checklists with predictions of total species richness from DNA barcoding studies (e.g., Hebert et al. 2016, Sheffield et al. 2017) shows that our knowledge of grassland arthropods is incomplete, except in the best-known taxonomic groups. Many checklists, including some of those summarised above, result from sampling brief windows of opportunity during the collecting season, perhaps as 
little as a few hours on one day of the year. A combination of factors, including weather, time of day, and phenology of component species, will affect the number of species collected, but the total will be less than the total species actually present. One solution is more intensive sampling throughout a season and in multiple habitats, and more ideally, over several years in succession. Some examples of long-term studies in grassland areas include the Ojibway Prairie in southwestern Ontario (Paiero et al. 2010), the St. Charles Rifle Range near Winnipeg Manitoba (Roughley et al. 2010; Wade and Roughley 2010), the Criddle/Vane homestead at Aweme, Manitoba (Holliday et al. 2014), aquatic insects of the Saskatchewan River near Saskatoon (Miyazaki and Lehmkuhl 2011), the wildlife reserve at Suffield Canadian Forces Base in Alberta (Finnamore and Buckle 1999), and the antelope brush grasslands near Osoyoos, British Columbia (Scudder 2000).

One of the most noteworthy of these locations has been the Criddle/Vane homestead at Aweme, located southeast of Brandon, Manitoba (Holliday et al. 2014). Arthropods have been collected sporadically at the site for over 115 years starting with Norman Criddle and his family (Holliday 2006). Representatives of the Moist Mixed Grassland and Lake Manitoba Plains Ecoregions are within a few kilometres of the homestead, along with remnant patches of tallgrass prairie. Records for carabid beetles collected at the site illustrate the value of such long-term data sets. Nearly 200 species have been collected at Aweme since 1900, representing 54\% of all species known from Manitoba (Holliday et al. 2014). The long-term record has also allowed researchers to track changes in species composition in recent studies compared with the 1900s. The introduction of crop monocultures and the use of insecticides are the main factors influencing ground beetle diversity (Holliday et al. 2014); not surprisingly, carabid diversity is low in agroecosystems.

One challenge to filling the knowledge gap about arthropods in the Prairie Ecozone is that some existing data and studies are in formats or collections that are not easily accessible to other researchers. Many lists and associated ecological information have been published in government or agency reports (e.g., Finnamore and Buckle 1999; Scudder 2000), and some of these are difficult to access. In other cases, amateur or retired entomologists have amassed collections or data that reside with the collector. Retired Memorial University entomology professor David Larson currently lives on a ranch south of Maple Creek, Saskatchewan on the southern slope of the Cypress Hills. His study of grassland arthropod diversity over the past 20 years has produced many new records and a wealth of collected material, but recent additions to the list are so far unpublished. Larson's working dataset updating the checklist of Saskatchewan Coleoptera (D. Larson, personal communication) lists about 2700 species, which dramatically increases the number of known species for Saskatchewan (compare to 2312 species in Hooper and Larson (2012) and 2679 species in Bousquet et al. (2013)). For the rove beetles alone (Staphylinidae), his sampling produced 12 new species and 50 new records for Saskatchewan (Klimaszewski et al. 2016). Larson's collections have also increased the known number of species of Lygaeoidea (Hemiptera) from the Prairie Provinces from 48 (Maw et al. 2000) to 68, including 50 species from southwestern Saskatchewan (most records published in Scudder 2009, 2010b, 2012, 2014a).

The need for more studies, especially for underrepresented taxa and habitats. Throughout its history, the BSC has worked to identify and fill knowledge gaps by encouraging researchers and interested amateurs to study poorly known taxa and regions. One objective of the Arthropods of Canadian Grasslands monograph series is to identify where information is lacking and direct study to those areas. For example, 398 species of carabids are known from the Prairies Ecozone, but no studies of this group have been done thus far in the Fescue Grassland, Cypress Upland, or the Boreal Transition Ecoregions (Holliday et al. 2014).

The BSC has sponsored BioBlitzes and curation blitzes to fill some of these gaps. Bioblitzes in the Prairies Ecozone contribute to the deposition of numerous specimens in the Canadian National Collection, regional collections at Agriculture and Agri-Food Canada research centres, and in university collections across the country. They have also introduced researchers and other interested collectors to one another and to new habitats that then become the focus of further study. However, 
specimens collected during these events can result in large numbers of unidentified specimens being deposited in museum collections due to a lack of taxonomic expertise. Thus, the BSC arranges curation blitzes that bring together taxonomists with diverse expertise to examine and identify this material. These, coupled with "citizen science" initiatives that include public participation, can help to fill in knowledge gaps in a cost-effective manner, especially for charismatic taxa such as butterflies, ladybird beetles (Coleoptera: Coccinellidae), bumble bees (Hymenoptera: Apidae), and dragonflies (Odonata). For example, an estimated 1.3 million volunteers recently participated in 388 biodiversity research projects in different locations around the world, reflecting an annual in-kind labour contribution of US \$2.5 billion (Theobald et al. 2015). Citizen scientists are an untapped resource of high potential for understanding species response to habitat loss and fragmentation, biological invasions, and the effects of climate change on grassland arthropods. Another advantage to launching citizen science projects within grasslands of Canada is that they have the potential to promote the public's understanding of the role of insects in ecosystems including aquatic ecosystems, agroecosystems, and urban ecosystems.

\section{Summary}

The Arthropods of Canadian Grasslands monograph series is the culmination of a near 40year project that reflects the efforts of a network of individuals working under the loose direction of the BSC. The initial objectives were to increase awareness of the vanishing grasslands of Canada and their associated arthropods, identify knowledge gaps, and provide direction for future studies of arthropods in these habitats. These objectives had to be expanded to increase the collaborator network. Thus, contributions to the series include general descriptions of the ecoregions that comprise the Prairies Ecozone, climate, a history of European colonisation, synopses of arthropod taxonomic groups, and studies of arthropod diversity in both select habitats (including agroecosystems) and specific grassland sites. The health of the network is fostered through newsletters, field trips, and conference symposia.
To highlight the plight of native grasslands in Canada to a broad audience, contributors to the series are encouraged to write not just for an academic audience, but in a manner that also will engage teachers, students, farmers, ranchers, naturalists, and other individuals interested in the Prairies Ecozone. Contributors also are encouraged to make use of colour images when possible for the same reason. This strategy of engaging researchers through activities sponsored by the BSC has thus far resulted in four volumes of Arthropods of Canadian Grasslands monograph series, has built a strong research network, and has fostered numerous collaborations. These collaborations have resulted in dozens of articles in scientific journals and newsletters, and book chapters, most of which are freely available online; e.g., see appendix 4.5 in Danks (2016) and references cited in this article. However, there remains a need for further study to better capture the diversity and ecology of Canadian grasslands arthropods, and to assess the effects of human activities in the Prairies Ecozone.

\section{Acknowledgements}

This is Lethbridge Research and Development Centre publication number 38717040 .

\section{References}

Aitchison, C.W. 1979. Winter-active subnivean invertebrates of southern Canada. I. Collembola. Pedobiologia, 19: 113-120.

Anderson, R.C. 2006. Evolution and origin of the central grassland of North America: climate, fire, and mammalian grazers. The Journal of the Torrey Botanical Society, 133: 626-647.

Anderson, R.S., Bouchard, P., and Douglas, H. 2014. Weevils (Coleoptera: Dryophthoridae, Curculionidae) of the Prairies Ecozone in Canada. In Arthropods of Canadian grasslands (volume 4): biodiversity and systematics part 2. Edited by D.J. Giberson and H.A. Cárcamo. Biological Survey of Canada, Ottawa, Ontario, Canada. Pp. 143-167.

Beaulieu, F. and Knee, W. 2014. Plant-feeding mites of the Canadian Prairies. In Arthropods of Canadian grasslands (volume 3): biodiversity and systematics part 1. Edited by H.A. Cárcamo and D.J. Giberson. Biological Survey of Canada, Ottawa, Ontario, Canada. Pp. 29-72.

Behan-Pelletier, V.M. 2003. Acari and Collembola biodiversity in Canadian agricultural soils. Canadian Journal of Soil Science, 83: 279-288. 
Behan-Pelletier, V.M. and Kanashiro, D. 2010. Acari in grassland soils of Canada. In Arthropods of Canadian grasslands (volume 1): ecology and interactions in grassland habitats. Edited by J.D. Shorthouse and K.D. Floate. Biological Survey of Canada, Ottawa, Ontario, Canada. Pp. 137-166.

Bennett, R. 1999. Canadian spider diversity and systematics. Newsletter of the Biological Survey of Canada (Terrestrial Arthropods), 18: 16-27.

Berg, N.W. and Pawluk, S. 1984. Soil mesofaunal studies under different vegetative regimes in North Central Alberta. Canadian Journal of Soil Science, 64: 209-223.

Blagoev, G.A., deWaard, J.R., Ratnasingham, S., deWaard, S.L., Lu, L., Robertson, J., et al. 2016. Untangling taxonomy: a DNA barcode reference library for Canadian spiders. Molecular Ecology Resources, 16: 325-341.

Bouchard, P. and Bousquet, Y. 2014. Darkling beetles (Coleoptera: Tenebrionidae) of Canadian grasslands. In Arthropods of Canadian grasslands (volume 4): biodiversity and systematics part 2. Edited by D.J. Giberson and H.A. Cárcamo. Biological Survey of Canada, Ottawa, Ontario, Canada. Pp. 119-140.

Bousquet, Y., Bouchard, P., Davies, A.E., and Sikes, D.S. 2013. Checklist of beetles (Coleoptera) of Canada and Alaska. Second edition. ZooKeys, 360: 1-44.

Bush, E.J., Loder, J.W., James, T.S., Mortsch, L.D., and Cohen, S.J. 2014. An overview of Canada's changing climate. In Canada in a changing climate: sector perspectives on impacts and adaptation. Edited by F.J. Warren and D.S. Lemmen. Government of Canada, Ottawa, Ontario, Canada. Pp. 23-64.

Byers, B. and Cárcamo, H. 2013. E.H. Strickland Alberta's first professional entomologist - one hundred years ago. Newsletter of the Biological Survey of Canada, 32: 8-9.

Cannings, R.A. 2014a. The dragonflies and damselflies (Odonata) of Canadian grasslands. In Arthropods of Canadian grasslands (volume 3): biodiversity and systematics part 1. Edited by H.A. Cárcamo and D.J. Giberson. Biological Survey of Canada, Ottawa, Ontario, Canada. Pp. 231-269.

Cannings, R.A. 2014b. The robber flies (Diptera: Asilidae) of western Canadian grasslands. In Arthropods of Canadian grasslands (volume 4): biodiversity and systematics part 2. Edited by D.J. Giberson and H.A. Cárcamo. Biological Survey of Canada, Ottawa, Ontario, Canada. Pp. 269-297.

Cárcamo, H.A. and Giberson, D.J. (editors). 2014. Arthropods of Canadian grasslands (volume 3): biodiversity and systematics part 1. Biological Survey of Canada, Ottawa, Ontario, Canada.

Cárcamo, H.A., Pinzón, J., Leech, R., and Spence, J.R. 2014. Spiders (Arachnida: Araneae) of the Canadian Prairies. In Arthropods of Canadian grasslands (volume 3): biodiversity and systematics part 1. Edited by H.A. Cárcamo and D.J. Giberson. Biological Survey of Canada, Ottawa, Ontario, Canada. Pp. 75-137.

Christiansen, K. and Bellinger, P. 1998. The Collembola of North America, north of the Rio Grande. Grinell College, Grinnell, Iowa, United States of America.
Cobb, D.G. and Flannagan, J.F. 1990. Trichoptera and substrate stability in the Ochre River, Manitoba. Hydrobiologia, 206: 29-38.

Coristine, L.E. and Kerr, J.T. 2011. Habitat loss, climate change, and emerging conservation challenges in Canada. Canadian Journal of Zoology, 89: 435-451.

Currie, D.C. 2014. Black flies (Diptera: Simuliidae) of the prairie grasslands of Canada. In Arthropods of Canadian grasslands (volume 3): biodiversity and systematics part 1. Edited by H.A. Cárcamo and D.J. Giberson. Biological Survey of Canada, Ottawa, Ontario, Canada. Pp. 371-387.

Danks, H.V. (editor). 1979. Canada and its insect fauna. Memoirs of the Entomological Society of Canada, 108: $1-573$.

Danks, H.V. 1988. The insects of Canada. A synopsis prepared for the delegates of the XVIII International Congress of Entomology, Vancouver, 1988. Biological Survey of Canada (Terrestrial Arthropods), Ottawa, Ontario, Canada.

Danks, H.V. 2016. The Biological Survey of Canada: a personal history. Monograph Series, 8: 1-180.

Danks, H.V. 2017. Benefits and principles of the Biological Survey of Canada: a model for scientific cooperation. The Canadian Entomologist, doi:10. 4039/tce.2017.24.

De Clerck-Floate, R. and Cárcamo, H. 2011. Biocontrol arthropods: new denizens of Canada's grassland agroecosystems. In Arthropods of Canadian grasslands (volume 2): inhabitants of a changing landscape. Edited by K.D. Floate. Biological Survey of Canada, Ottawa, Ontario, Canada. Pp. 291-321.

Desserud, P., Gates, C.C., Adams, B., and Revel, R.D. 2010. Restoration of foothills rough fescue grassland following pipeline disturbance in southwestern Alberta. Journal of Environmental Management, 91: 2763-2770.

DeWalt, R.E., Maehr, M.D., Neu-Becker, U., and Stueber, G. 2017. Plecoptera species file online. Version 5.0/5.0 [online]. Available from http:// Plecoptera.SpeciesFile.org [accessed 20 March 2017].

Dosdall, L.M. and Giberson, D.J. 2014. Stoneflies (Plecoptera) of the Canadian Prairie Provinces. In Arthropods of Canadian grasslands (volume 3): biodiversity and systematics part 1. Edited by H.A. Cárcamo and D.J. Giberson. Biological Survey of Canada, Ottawa, Ontario, Canada. Pp. 201-229.

Ecological Stratification Working Group. 1995. A national ecological framework for Canada. Edited by Agriculture and Agri-Food Canada, Centre for Land and Biological Resources Research, and Environment Canada, State of the Environment Directorate, Ecozone Analysis Branch. Minister of Supply and Services Canada, Ottawa/Hull, Ontario/ Québec, Canada.

Finnamore, A.T. and Buckle, D.J. 1999. Arthropod component report. The stinging wasps (Hymenoptera: Chrysidoidea, Vespoidea, Apoidea) and spiders (Araneae). Canadian Forces Base Suffield National Wildlife Area. Wildlife inventory. The Provincial Museum of Alberta, Edmonton, Alberta, Canada. Pp. 197. 
Floate, K.D. 2011a. Arthropods in cattle dung on Canada's grasslands. In Arthropods of Canadian grasslands (volume 2): inhabitants of a changing landscape. Edited by K.D. Floate. Biological Survey of Canada, Ottawa, Ontario, Canada. Pp. 71-88.

Floate, K.D. (editor). 2011b. Arthropods of Canadian grasslands. (volume 2): inhabitants of a changing landscape. Biological Survey of Canada, Ottawa, Ontario, Canada.

Foottit, R.G. and Maw, E. 2014. Aphids (Hemiptera: Aphidoidea) of the Prairie Ecozone of Canada. In Arthropods of Canadian grasslands (volume 3): biodiversity and systematics part 1. Edited by Cárcamo H.A. and D.J. Giberson. Biological Survey of Canada, Ottawa, Ontario, Canada. Pp. 347-369.

Galloway, T.D., Proctor, H.C., and Mironov, S.V. 2014. Chewing lice (Insecta: Phthiraptera: Amblycera, Ischnocera) and feather mites (Acari: Astigmatina: Analgoidea, Pterolichoidea): ectosymbionts of grassland birds in Canada. In Arthropods of Canadian grasslands (volume 3): biodiversity and systematics part 1. Edited by H.A. Cárcamo and D.J. Giberson. Biological Survey of Canada, Ottawa, Ontario, Canada. Pp. 139-188.

Giberson, D.J. and Cárcamo, H.A. (editors). 2014. Arthropods of Canadian grasslands. (volume 4): biodiversity and systematics part 2. Biological Survey of Canada, Ottawa, Ontario, Canada.

Gibson, A. and Crawford, H. 1933. Norman Criddle. The Canadian Entomologist, 65: 193-200.

Giribet, G. and Edgecombe, G.D. 2012. Reevaluating the arthropod tree of life. Annual Review of Entomology, 57: 167-186.

Glasier, J.R.N. and Acorn, J.H. 2014. An annotated list of ants (Hymenoptera: Formicidae) from the grasslands of Alberta and Saskatchewan. In Arthropods of Canadian grasslands (volume 4): biodiversity and systematics part 2. Edited by D.J. Giberson and H.A. Cárcamo. Biological Survey of Canada, Ottawa, Ontario, Canada. Pp. 299-314.

Grothman, G.T. 2011. Tardigrades of Fish Creek Provincial Park, Alberta, Canada: a preliminary survey. The Canadian Field-Naturalist, 125: 22-26.

Hall, P.W., Catling, P.M., and Lafontaine, J.D. 2011. Insects at risk in the prairie region. In Arthropods of Canadian grasslands (volume 2): inhabitants of a changing landscape. Edited by K.D. Floate. Biological Survey of Canada, Ottawa, Ontario, Canada. Pp. 323-349.

Hamilton, K.G.A. 2014. Canadian grasslands and their endemic leafhoppers (Hemiptera: Auchenorrhyncha: Cicadellidae). In Arthropods of Canadian grasslands (volume 3): biodiversity and systematics part 1. Edited by H.A. Cárcamo and D.J. Giberson. Biological Survey of Canada, Ottawa, Ontario, Canada. Pp. 311-345.

Hamilton, K.G.A. and Whitcomb, R.F. 2010. Leafhoppers (Homoptera: Cicadellidae): a major family adapted to grassland habitats. In Arthropods of Canadian grasslands (volume 1): ecology and interactions in grassland habitats. Edited by J.D. Shorthouse and K.D. Floate. Biological Survey of Canada, Ottawa, Ontario, Canada. Pp. 169-197.
Hebert, P.D.N., Ratnasingham, S., Zakharov, E.V., Telfer, A.C., Levesque-Beaudin, V., Milton, M.A., et al. 2016. Counting animal species with DNA barcodes: Canadian insects. Philosophical Transactions of the Royal Society B: Biological Sciences, 371: 20150333.

Hocking, B. 1963. Edgar Harold Strickland, M.Sc., D.Sc., F.E.S.A., F.R.S.C. The Canadian Entomologist, 95: 292-296.

Holliday, N.J. 2006. Norman Criddle: pioneer entomologist of the Prairies [online]. In Manitoba History. Manitoba Historical Society. Available from www.mhs.mb.ca/docs/mb_history/51/criddle_n.shtml [accessed 30 June 2017].

Holliday, N.J., Floate, K.D., Cárcamo, H., Pollock, D.A., Stjernberg, A., and Roughley, R.E. 2014. Ground beetles (Coleoptera: Carabidae) of the prairie grasslands of Canada. In Arthropods of Canadian Grasslands (volume 4): biodiversity and systematics part 2. Edited by H.A. Cárcamo and D.J. Giberson. Biological Survey of Canada, Ottawa, Ontario, Canada. Pp. 1-85.

Holmberg, R.G. and Buckle, D.J. 2002. Prairie spiders of Alberta and Saskatchewan. Arthropods of Canadian Grasslands, 8: 11-15.

Hooper, R.R. and Larson, D.J. 2012. Checklist of beetles (Coleoptera: Insecta) of Saskatchewan [online]. Available from www.entsocsask.ca/documents/ insect_lists/Coleoptera\%20Species\%20List\%20of\%20 SK_copy.pdf [accessed 30 June 2017].

Horikawa, D.D. 2012. Survival of tardigrades in extreme environments: a model animal for astrobiology. In Anoxia: evidence for eukaryote survival and paleontological strategies. Edited by A.V. Altenbach, J.M. Bernhard, and J. Seckbach. Springer, Dordrecht, The Netherlands. Pp. 205-217.

Jacobus, L. and McCafferty, P. 2017. Mayfly central North America species list. Species list and current names and synonyms [online]. Available from www.entm.purdue.edu/mayfly/na-species-list. php [accessed 3 May 2017].

Klimaszewski, J., Godin, B., Bourdon, C., Langor, D., Lee, S.-I., and Horwood, D. 2015. New distribution records for Canadian Aleocharinae (Coleoptera, Staphylinidae), and new synonymies for Trichiusa. ZooKeys, 498: 51-91.

Klimaszewski, J., Larson, D.J., Labrecque, M., and Bourdon, C. 2016. Twelve new species and fiftythree new provincial distribution records of Aleocharinae rove beetles of Saskatchewan, Canada (Coleoptera, Staphylinidae). ZooKeys, 610: 45-112.

Larson, D.J., Alarie, Y., and Roughley, R.E. 2000. Predaceous diving beetles (Coleoptera: Dytiscidae) of the Nearctic Region, with emphasis on the fauna of Canada and Alaska. National Research Council Press, Ottawa, Ontario, Canada.

Lindo, Z. 2014. Springtails (Hexapoda: Collembola) of the Prairie Grasslands of Canada. In Arthropods of Canadian grasslands (volume 3): biodiversity and systematics part 1. Edited by H.A. Cárcamo and D.J. Giberson. Biological Survey of Canada, Ottawa, Ontario, Canada. Pp. 191-198. 
Lindquist, E.E., Ainscough, B.D., Clulow, F.V., Funk, R.C., Marshall, V.G., Nesbitt, H.H.J., et al. 1979. Acari. In Canada and its insect fauna. Edited by H.V. Danks. Memoirs of the Entomological Society of Canada, 108: 252-290.

Lindquist, E.E., Galloway, T.D., Artsob, H., Lindsay, L.R., Drebot, M., Wood, H., and Robbins, R.G. 2016. A handbook to the ticks of Canada (Ixodida: Ixodidae, Argasidae). Biological Survey of Canada Monograph Series, 7: 1-317.

Lindroth, C.H. 1961-1969. The ground beetles (Carabidae, excl. Cicindelininae) of Canada and Alaska: parts 1-6. Opuscula Entomologica Supplement, 20, 24, 29, 33, 34, 35: 1-1192.

Lumley, L., Beaulieu, F., Behan-Pelletier, V.M., Knee, W., Lindquist, E.E., Mark, M., et al. 2013. The status of systematic knowledge of the Acari of Canada: tickin' away with some mitey progress. Newsletter of the Biological Survey of Canada (Terrestrial Arthropods), 32: 23-37.

Lysyk, T.J. and Galloway, T.D. 2014. Biting flies (Culicidae, Ceratopogonidae, Tabanidae) of the Prairies Ecozone. In Arthropods of Canadian grasslands (volume 3): biodiversity and systematics part 1. Edited by H.A. Cárcamo and D.J. Giberson. Biological Survey of Canada, Ottawa, Ontario, Canada. Pp. 389-398.

Mason, P.G. 1983. Systematics and ecology of Chironomidae (Diptera) associated with Tobin Lake Reservoir and the Saskatchewan River. PhD thesis. University of Saskatchewan, Saskatoon, Saskatchewan, Canada.

Maw, H.E.L., Foottit, R.G., Hamilton, K.G.A., and Scudder, G.G.E. 2000. Checklist of the Hemiptera of Canada and Alaska. National Research Council Press, Ottawa, Ontario, Canada.

McGinn, S.M. 2010. Weather and climate patterns in Canada's prairie grassland. In Arthropods of Canadian grasslands (volume 1): ecology and interations in grassland habitats. Edited by J.D. Shorthouse and K.D. Floate. Biological Survey of Canada, Ottawa, Ontario, Canada. Pp. 105-119.

Memmott, J., Craze, P.G., Waser, N.M., and Price, M.V. 2007. Global warming and the disruption of plant-pollinator interactions. Ecology Letters, 10: 710-717.

Merritt, R.W., Cummins, K.W., and Berg, M.B. (editors). 2008. An introduction to the aquatic insects of North America, 4th edition, Kendall/Hunt Publishing Company, Dubuque, Iowa, United States of America.

Miskelly, J. 2014. Orthoptera of the grasslands of British Columbia and the Yukon territory. In Arthropods of Canadian grasslands (volume 3): biodiversity and systematics part 1. Edited by H.A. Cárcamo and D.J. Giberson. Biological Survey of Canada, Ottawa, Ontario, Canada. Pp. 271-281.

Miyazaki, R. and Lehmkuhl, D.M. 2011. Insects of the Saskatchewan River system in Saskatchewan. In Arthropods of Canadian grasslands (volume 2): inhabitants of a changing landscape. Edited by K.D. Floate. Biological Survey of Canada, Ottawa, Ontario, Canada. Pp. 119-157.
Nantel, P., Pellatt, M.G., Keenleyside, K., and Gray, P.A. 2014. Biodiversity and protected areas. In Canada in a changing climate: sector perspectives on impacts and adaptation. Edited by F.J. Warren and D.S. Lemmen. Government of Canada, Ottawa, Ontario, Canada. Pp. 159-190.

Olfert, O. and Weiss, R.M. 2006. Impact of climate change on potential distributions and relative abundances of Oulema melanopus, Meligethes viridescens and Ceutorhynchus obstrictus in Canada. Agriculture, Ecosystems and Environment, 113: 295-301.

Olfert, O., Weiss, R.M., and Elliott, R.H. 2016. Bioclimatic approach to assessing the potential impact of climate change on wheat midge (Diptera: Cecidomyiidae) in North America. The Canadian Entomologist, 148: 52-67.

Olfert, O., Weiss, R.M., and Kriticos, D. 2011. Application of general circulation models to assess the potential impact of climate change on potential distribution and relative abundance of Melanoplus sanguinipes (Fabricius) (Orthoptera: Acrididae) in North America. Psyche, 2011: 980372.

Paiero, S.M., Marshall, S.A., Pratt, P.D., and Buck, M. 2010. Insects of Ojibway Prairie, a southern Ontario tallgrass prairie. In Arthropods of Canadian grasslands (volume 1): ecology and interactions in grassland habitats. Edited by J.D. Shorthouse and K.D. Floate. Biological Survey of Canada, Ottawa, Ontario, Canada. Pp. 199-225.

Paquin, P., Buckle, D.J., Dupérré, N., and Dondale, C.D. 2010. Checklist of the spiders (Araneae) from Alaska and Canada. Zootaxa, 2461: 1-170.

Parker, D. 2017. Saskatchewan aquatic macroinvertebrate web page [online]. Available from www.aquatax.ca/skAquaticInsectInfo.html [accessed 20 March 2017].

Pearn, M. and Hamel, C. (editors). 2014. Proceedings of the Manitoba tall grass prairie preserve research symposium. Nature Conservancy of Canada, Winnipeg, Manitoba, Canada.

Pieper, R.D. 2005. Grasslands of central North America. In Grasslands of the world. Edited by J.M. Suttie, S.G. Reynolds, and C. Batello. Food and Agriculture Organization of the United Nations, Rome, Italy. Pp. 221-263.

Pohl, G.R., Schmidt, B.C., Lafontaine, J.D., Landry, J.-F., Anweiler, G.G., and Bird, C.D. 2014. Moths and butterflies of the Prairies Ecozone in Canada. In Arthropods of Canadian grasslands (volume 4): biodiversity and systematics part 2. Edited by D.J. Giberson and H.A. Cárcamo. Biological Survey of Canada, Ottawa, Ontario, Canada. Pp. 169-238.

Qian, B., Zhang, X., Chen, K., Feng, Y., and O'Brien, T. 2010. Observed long-term trends for agroclimatic conditions in Canada. Journal of Applied Meteorology and Climatology, 49: 604-618.

Rasmussen, A.K. and Morse, J.C. 2016. Distributional checklist of Nearctic Trichoptera (Summer 2016 revision). Florida A\&M University, Tallahassee, Florida, United States of America. 
Roughley, R.E., Pollock, D.A., and Wade, D.J. 2010. Tallgrass prairie, ground beetles (Coleoptera: Carabidae), and the use of fire as a biodiversity and conservation management tool. In Arthropods of Canadian grasslands (volume 1): ecology and interactions in grassland habitats. Edited by J.D. Shorthouse and K.D. Floate. Biological Survey of Canada, Ottawa, Ontario, Canada. Pp. 227-235.

Sauchyn, D. and Kulshreshtha, S. 2008. Prairies. In From impacts to adaptation: Canada in a changing climate. Edited by D.S. Lemmen, F.J. Warren, J. Lacroix, and E. Bush. Government of Canada, Ottawa, Ontario, Canada. Pp. 275-328.

Scheffczyk, A., Floate, K.D., Blanckenhorn, W.U., Düring, R.-A., Klockner, A., Lahr, J., et al. 2016. Nontarget effects of ivermectin residues on earthworms and springtails dwelling beneath dung of treated cattle in four countries. Environmental Toxicology and Chemistry, 35: 1959-1969.

Schwarzfeld, M.D. 2014. Ichneumonidae (Hymenoptera) of the Canadian Prairies Ecozone: a review. In Arthropods of Canadian grasslands (volume 4): biodiversity and systematics part 2. Edited by D.J. Giberson and H.A. Cárcamo. Biological Survey of Canada, Ottawa, Ontario, Canada. Pp. 317-397.

Scudder, G.G.E. 2000. The Osoyoos Desert Society: experimental studies on ecological restoration of the shrub-steppe habitat. internal report. In Proceedings of a conference on the biology and management of species and habitats at risk, 15-19 February 1999. Edited by L.M. Darling. British Columbia Ministry of Environment, Lands and Parks, Victoria, British Columbia, Canada and University College of the Cariboo, Kamloops, British Columbia, Canada. Pp. 797-800.

Scudder, G.G.E. 2009. Nine Heteroptera (Hemiptera) new to Canada, with additional new provincial records for three other species in Canada. Journal of the Entomological Society of British Columbia, 106: $3-9$.

Scudder, G.G.E. 2010a. Grasslands: biodiversity hotspots for some arthropods in British Columbia. In Arthropods of Canadian grasslands (volume 1): ecology and interactions in grassland habitats. Edited by J.D. Shorthouse and K.D. Floate. Biological Survey of Canada, Ottawa, Ontario, Canada. Pp. 121-134.

Scudder, G.G.E. 2010b. Melacoryphus admirabilis (Uhler) (Hemiptera: Lygaeidae) new to Canada, with additional Canadian provincial records for other Heteroptera. Journal of the Entomological Society of British Columbia, 107: 3-9.

Scudder, G.G.E. 2012. Additional provincial and state records for Heteroptera (Hemiptera) in Canada and the United States. Journal of the Entomological Society of British Columbia, 109: 55-69.

Scudder, G.G.E. 2014a. The Heteroptera (Hemiptera) of the Prairies Ecozone of Canada. In Arthropods of Canadian grasslands (volume 3 ): biodiversity and systematics part 1. Edited by H.A. Cárcamo and D.J. Giberson. Biological Survey of Canada, Ottawa, Ontario, Canada. Pp. 283-309.
Scudder, G.G.E. 2014b. An introduction to the biogeography of Canadian grassland arthropods. In Arthropods of Canadian grasslands (volume 3): biodiversity and systematics part 1. Edited by H.A. Cárcamo and D.J. Giberson. Biological Survey of Canada, Ottawa, Ontario, Canada. Pp. 1-19.

Sharanowski, B.J., Zhang, Y.M., and Wanigasekara, R.W.M.U.M. 2014. Annotated checklist of Braconidae (Hymenoptera) in the Canadian Prairies Ecozone. In Arthropods of Canadian grasslands (volume 4): biodiversity and systematics part 2 . Edited by D.J. Giberson and H.A. Cárcamo. Biological Survey of Canada, Ottawa, Ontario, Canada. Pp. 399-425.

Sheffield, C.S., Frier, S.D., and Dumesh, S. 2014. The bees (Hymenoptera: Apoidea, Apiformes) of the Prairies Ecozone, with comparisons to other grasslands of Canada. In Arthropods of Canadian grasslands (volume 4): biodiversity and systematics part 2. Edited by D.J. Giberson and H.A. Cárcamo. Biological Survey of Canada, Ottawa, Ontario, Canada. Pp. 427-467.

Sheffield, C.S., Heron, J., Gibbs, J., Onuferko, T.M., Oram, R., Best, L., et al. 2017. DNA barcoding the bees (Hymenoptera: Apoidea) of Canada: progress to date. The Canadian Entomologist, doi:10.4039/tce.2017.49.

Shorthouse, J.D. 2010a. Canada's grasslands as habitat for arthropods. In Arthropods of Canadian grasslands (volume 1): ecology and interations in grassland habitats. Edited by J.D. Shorthouse and K.D. Floate. Biological Survey of Canada, Ottawa, Ontario, Canada. Pp. 27-51.

Shorthouse, J.D. 2010b. Ecoregions of Canada's prairie grasslands. In Arthropods of Canadian grasslands (volume 1): ecology and interations in grassland habitats. Edited by J.D. Shorthouse and K.D. Floate. Biological Survey of Canada, Ottawa, Ontario, Canada. Pp. 53-81.

Shorthouse, J.D. 2010c. Ecoregions with grasslands in British Columbia, the Yukon, and southern Ontario. In Arthropods of Canadian grasslands (volume 1): ecology and interations in grassland habitats. Edited by J.D. Shorthouse and K.D. Floate. Biological Survey of Canada, Ottawa, Ontario, Canada. Pp. 83-103.

Shorthouse, J.D. and Floate, K.D. (editors). 2010. Arthropods of Canadian grasslands. (volume 1): ecology and interactions in grassland habitats. Biological Survey of Canada, Ottawa, Ontario, Canada.

Skidmore, R.E. 1995. Checklist of Collembola (Insecta: Apterygota) of Canada and Alaska. Proceedings of the Entomological Society of Ontario, 126: 45-76.

Skinner, W.R. and Gullett, D.W. 1993. Trends of daily maximum and minimum temperature in Canada during the past century. Climatology Bulletin, 27: 63-77.

Snyder, B.A. 2014. Myriapoda and terrestrial Isopoda of the prairies of Canada. In Arthropods of Canadian grasslands (volume 3): biodiversity and systematics part 1. Edited by H.A. Cárcamo and D.J. Giberson. Biological Survey of Canada, Ottawa, Ontario, Canada. Pp. 21-27. 
Sorensen, J. and Goater, C. 2016. Tardigrades on mosses from southern Alberta grasslands: extraction, occurrence, and density. Newsletter of the Biological Survey of Canada (Terrestrial Arthropods), 35: 9-13.

Statistics Canada. 2006. Table 2. Population, by terrestrial ecozone, 1981 to 2006 [online]. Available from www.statcan.gc.ca/pub/16-002-x/2008002/t/5212 697-eng.htm [accessed 30 June 2017].

Theobald, E.J., Ettinger, A.K., Burgess, H.K., DeBey, L.B., Schmidt, N.R., Froehlich, H.E., et al. 2015. Global change and local solutions: tapping the unrealized potential of citizen science for biodiversity research. Biological Conservation, 181: 236-244.

van Herk, W.G. and Vernon, R.S. 2014. Click beetles and wireworms (Coleoptera: Elateridae) of Alberta, Saskatchewan, and Manitoba. In Arthropods of Canadian grasslands (volume 4): biodiversity and systematics part 2. Edited by D.J. Giberson and H.A. Cárcamo. Biological Survey of Canada, Ottawa, Ontario, Canada. Pp. 87-117.

Vickery, V.R. and Kevan, D.K.M. 1985. The grasshoppers, crickets, and related insects of Canada and adjacent regions. Ulonata: Dermaptera, Cheleutoptera, Notoptera, Dictuoptera, Grylloptera, and Orthoptera. The Insects and Arachnids of Canada, Part 14. Publication 1777. Canadian Government Publishing Centre, Ottawa, Ontario, Canada.

Vujnovic, K., Wein, R.W., and Dale, M.R.T. 2002. Predicting plant species diversity in response to disturbance magnitude in grassland remnants of central Alberta. Canadian Journal of Botany, 80: 504-511.
Wade, D.J. and Roughley, R.E. 2010. Responses of a tallgrass prairie spider (Araneae) community to various burn seasons and its importance to tallgrass prairie management. In Arthropods of Canadian grasslands (volume 1): ecology and interactions in grassland habitats. Edited by J.D. Shorthouse and K.D. Floate. Biological Survey of Canada, Ottawa, Ontario, Canada. Pp. 237-249.

Webb, J.M. 2002. The mayflies of Saskatchewan. MSc thesis. University of Saskatchewan, Saskatoon, Saskatchewan, Canada.

White, F. 1983. The vegetation of Africa: a descriptive memoir to accompany the UNESCO/AETFAT/ UNSO vegetation map of Africa. United Nations Educational, Scientific, and Cultural Organization, Paris, France.

Willms, W., Adams, B., and McKenzie, R. 2011. Overview: anthrogenic changes of Canadian grasslands. In Arthropods of Canadian grasslands (volume 2): inhabitants of a changing landscape. Edited by K.D. Floate. Biological Survey of Canada, Ottawa, Ontario, Canada. Pp. 1-22.

Wrubleski, D.A. and Ross, L.C.M. 2011. Aquatic invertebrates of prairie wetlands: community composition, ecological roles, and impacts of agriculture. In Arthropods of Canadian grasslands (volume 2): inhabitants of a changing landscape. Edited by K.D. Floate. Biological Survey of Canada, Ottawa, Ontario, Canada. Pp. 91-116. 